\title{
Drug Shortages in Canada and Selected European Countries: A Cross-Sectional, Institution-Level Comparison
}

\author{
Manon Videau, Lotfi Chemali, Cyril Stucki, Mar Saavedra-Mitjans, Samuel Largana, Aurélie Guerin, \\ Pascal Bonnabry, Blaise Delhauteur, Thierry Van Hees, Denis Lebel, and Jean-François Bussières
}

\begin{abstract}
Background: Drug shortages represent a complex global problem affecting patients and health care professionals on a daily basis.

Objectives: To identify, describe, and compare drug shortages in health care facilities in Canada and 4 European countries in early 2018.

Methods: A descriptive cross-sectional study was conducted in 1 hospital in each of 5 countries: Canada, France, Belgium, Spain, and Switzerland. Over a 4-week period, shortage data were collected daily by each hospital using a standardized grid and a standard process.

Results: From January 8 to February 2, 2018, there were a total of 84 shortages (median duration 32 days) in the Canadian hospital, 62 shortages (median duration 9 days) in the French hospital, 46 shortages (median duration 37 days) in the Belgian hospital, 28 shortages (median duration 25 days) in the Spanish hospital, and 98 shortages (median duration 68 days) in the Swiss hospital. The number of manufacturers implicated in the shortages was 28 for the Canadian hospital, 30 for the French hospital, 19 for the Belgian hospital, 16 for the Spanish hospital, and 42 for the Swiss hospital. Most of the shortages involved parenteral drugs, with both innovative and generic manufacturers being affected. Most therapeutic classes were affected by shortages to some extent, with the top 3 classes being anti-infective agents (accounting for 21.1\% of shortages overall), central nervous system drugs (11.3\%), and cardiovascular drugs (8.2\%).
\end{abstract}

Conclusions: Drug shortages occurred almost daily in all of the study hospitals. Across the 5 hospitals, the frequency of shortages varied by a factor of 3, which may imply similar variability at the national level. All stakeholders should work more diligently to prevent and manage drug shortages.

Keywords: drug shortages, pharmaceutical practice, drug supply

Can J Hosp Pharm. 2019;72(1):7-15

\section{RÉSUMÉ}

Contexte : Les pénuries de médicaments représentent un problème mondial complexe qui touche quotidiennement les patients et les professionnels de la santé.

Objectifs : Recenser, décrire et comparer les pénuries de médicaments ayant eu lieu au début de 2018 dans des établissements de soins de santé du Canada et de quatre pays d'Europe.

Méthodes : Une étude descriptive et transversale a été menée dans un hôpital de chacun des cinq pays suivants : le Canada, la France, la Belgique, l'Espagne et la Suisse. Sur une période de quatre semaines, chaque hôpital a recueilli quotidiennement les données sur les pénuries à l'aide d'une grille et d'un processus normalisés.

Résultats : Pour la période allant du 8 janvier au 2 février 2018, on a recensé 84 pénuries (durée médiane de 32 jours) dans l'hôpital canadien, 62 pénuries (durée médiane de 9 jours) dans l'hôpital français, 46 pénuries (durée médiane de 37 jours) dans l'hôpital belge, 28 pénuries (durée médiane de 25 jours) dans l'hôpital espagnol et 98 pénuries (durée médiane de 68 jours) dans l'hôpital suisse. Vingt-huit (28) fabricants étaient impliqués dans les cas de pénuries dans l'hôpital canadien, 30 dans l'hôpital français, 19 dans l'hôpital belge, 16 dans l'hôpital espagnol et 42 dans l'hôpital suisse. La plupart des pénuries touchaient les médicaments parentéraux et mettaient en cause tant les fabricants de médicaments novateurs que ceux de médicaments génériques. Les pénuries ont affecté d'une manière ou d'une autre la plupart des classes de médicaments, mais les trois classes les plus touchées étaient les agents anti-infectieux $(21,1 \%)$ les médicaments agissant sur le système nerveux central $(11,3 \%)$ et les agents cardiovasculaires $(8,2 \%)$.

Conclusions : Des pénuries survenaient presque quotidiennement dans chaque hôpital de l'étude. Dans l'ensemble des hôpitaux, la fréquence des pénuries variait selon un facteur de trois, ce qui pourrait se traduire par une variabilité semblable à l'échelle nationale. Toutes les parties prenantes doivent travailler avec plus d'ardeur à la prévention et à la gestion des pénuries de médicaments.

Mots clés : pénuries de médicaments, pratique pharmaceutique, approvisionnement en médicaments 
This single copy is for your personal, non-commercial use only.

For permission to reprint multiple copies or to order presentation-ready copies for distribution, contact CJHP at publications@cshp.ca

\section{INTRODUCTION}

$\mathrm{T}$ he World Health Organization (WHO) views drug shortages as a complex global challenge. ${ }^{1}$ Numerous signs point to the growing importance of this issue, particularly in Europe and North America. ${ }^{2,3}$ One of the most striking examples in recent years in Canada was the Sandoz crisis, which involved a production slowdown and shortages of hundreds of injectable drugs. As a result, warning letters were issued to Sandoz Canada by the US Food and Drug Administration in 2011 and 2012. Although the problem of shortages affects many countries, there is still too little information available to allow researchers to determine the extent and characteristics of this phenomenon internationally. ${ }^{4}$ Moreover, international benchmarking of drug shortages on the basis of available data is difficult, because a uniform definition of drug shortages is lacking. ${ }^{5}$ For example, the WHO recently identified 56 definitions of drug shortages currently in use around the world. ${ }^{6}$

Drug shortages have become a major public health issue, and international bodies such as the WHO, the International Pharmaceutical Federation, and the European Association of Hospital Pharmacists are increasingly undertaking initiatives to prevent and address such shortages. ${ }^{7-10}$ However, the measures taken, including formal regulations, vary widely from one country to another. ${ }^{4}$ In terms of the regulatory framework, notification of drug shortages to one or more national authorities has been mandatory since 2004 in France, ${ }^{11}$ since 2006 in Belgium, ${ }^{12}$ since 2010 in Spain, ${ }^{13}$ and since 2015 in Switzerland. ${ }^{14}$ In Canada, such declarations have been mandatory only since 2017. ${ }^{15}$ More generally in Europe, article 23a of directive 2001/83/EC of the European Commission specifies that market authorization holders for products marketed in member states of the European Union are required to give 2 months' notice to regulatory authorities when market access to a product will be temporarily or permanently interrupted. ${ }^{16}$

In the hospital setting, pharmacists must ensure the supply of drugs to meet the needs of all patients and must responsibly manage the integrity of the supply chain (e.g., appropriate allocation of available quantities of drugs through prioritization of patients). ${ }^{17}$ Therefore, it is important for pharmacists to stay informed about ongoing shortages, remain proactive in addressing them, and know what alternative resources are available to treat patients.

Regardless of the cause of a drug shortage, the consequences for public health can be serious and are unlikely to respect national borders. ${ }^{118}$ Furthermore, despite existing measures, drug shortages remain a major problem affecting patients and clinicians on a daily basis. ${ }^{19}$ A study of national-level data, published in 2017, found more drug shortages in Canada than in France, although the number of shortages was similar in a sample hospital from each country. ${ }^{20}$ The study reported here therefore aimed to supplement and expand upon those earlier data by identifying, describing, and comparing drug shortages in 1 representative health facility from Canada and each of 4 European countries.

\section{METHODS}

This descriptive cross-sectional study involved 1 hospital in each of 5 countries. Drug shortage data were obtained from a university hospital in each of Canada (456 acute care beds), France (600 beds), Spain (600 beds), and Switzerland (1000 beds) and from a general hospital in Belgium (900 beds). The French and Canadian hospitals bought drugs through drug wholesalers, whereas the hospitals in the other 3 countries obtained drugs directly from the manufacturers. The hospitals were identified through previous collaborations with our Canadian research unit. In each hospital, an individual hospital pharmacist or a pair of workers (consisting of a pharmacist and a pharmacist student) were identified to provide the requested data.

\section{Data Sources and Data Extraction}

For the purpose of this study, a drug was defined as a product having a specific content, form, or size that was obtained from a particular manufacturer (e.g., amoxicillin, 500-mg capsules, box of 100 capsules, Mylan). If more than one drug manufacturer was in shortage for a given medication in a given national market, the shortage of that medication was counted as a single event for the hospital. A drug shortage was identified by failure on the part of the supplier to deliver an ordered product to the hospital, because of a supply problem for the product at the particular supplier; no time criteria were applied, because failure to deliver an ordered product to a hospital may have consequences, regardless of the duration of the shortage. Participating personnel at each hospital collected the data daily from January 8 to February 2, 2018, using a standardized grid (Excel spreadsheet, Microsoft Corporation) and a standard data-collection process. To ensure a complete set of data for drug-related shortages during the study period, all active shortages known by the data collectors in their respective hospitals were documented on January 8, and any new shortages that occurred during the study period were recorded.

From the data collected, a start date and an end date (date of return to stock or withdrawal from the market) were identified for each drug in shortage. When the actual start and end dates of the shortage were known, these dates were used. Otherwise, the estimated start date of the shortage and the estimated date of return to stock were used to calculate the duration of the shortage. For drugs with an estimated date of return to the market later than February 2, 2018, the end date was arbitrarily defined as February 2, 2018. For each drug in short supply, we identified the manufacturer, type of manufacturer (innovative or generic), therapeutic class (according to the Anatomical Therapeutic Chemical Classification System or the American Hospital Formulary Service classification), and the route of administration (parenteral or otherwise). 
In addition, for each drug shortage, we collected the source of the information about the shortage, the main cause of the shortage, the presence of a national guideline concerning the particular shortage, the function of the person who was primarily responsible for managing the shortage within the hospital, any action taken to address the shortage, and an estimate of the time required to manage the shortage (e.g., to gather information, communicate with patients and colleagues, search for and order alternative treatment, or perform pharmaceutical compounding in the pharmacy).

\section{Descriptive Analysis}

For each country, we calculated the number of drugs in short supply, the average or median duration of shortages (according to the data distribution), the number of manufacturers implicated by shortages, the proportion of drug shortages associated with generic drugs, and the proportion of shortages involving drugs administered by the parenteral route. Also, respondents were asked to identify additional management strategies and tools in place.

\section{Comparison of Drug Shortage Ratios}

For each hospital, the drug shortage ratio was defined as the ratio of total number of shortages identified to the total number of drugs normally in stock at the facility. Drug shortage ratios are reported for the 5 hospitals.

\section{RESULTS}

\section{Descriptive Analysis}

From January 8 to February 2, 2018, there were a total of 84 drug shortages in the Canadian hospital, 62 in the French hospital, 46 in the Belgian hospital, 28 in the Spanish hospital, and 98 in the Swiss hospital. The median duration of drug shortages was 32 days (range 0-402 days) in the Canadian hospital, 9 days (range 2-437 days) in the French hospital, 37 days (range 1-263 days) in the Belgian hospital, 25 days (range 0-240 days) in the Spanish hospital, and 68 days (range 0-1771 days) in the Swiss hospital (Table 1). The majority of drugs in short supply were for parenteral administration (60.1\%). Overall, the main therapeutic classes affected by drug shortages were anti-infective agents $(21.1 \%$ of shortages overall), central nervous system agents (11.3\%), cardiovascular drugs (8.2\%), and antineoplastic agents (7.5\%). Table 1 also shows the number of manufacturers affected by at least 1 drug shortage and the proportion of shortages involving generic drug manufacturers. The top 5 manufacturers involved in drug shortages across all 5 hospitals were Pfizer (9.7\%), MSD (6.3\%), Mylan (6.0\%), Sanofi (6.0\%), and GSK (5.0\%) (Table 2).

\section{Comparisons}

For calculating the drug shortage ratio at each hospital, the total number of drugs normally in stock was 2032 for the
Canadian hospital, 2034 for the French hospital, 1419 for the Belgian hospital, 2345 for the Spanish hospital, and 2362 for the Swiss hospital. The drug shortage ratios were calculated as $4.13 \%$, $3.05 \%, 3.24 \%, 1.19 \%$, and $4.15 \%$, respectively.

\section{Qualitative Analysis}

The main sources of information regarding drugs in short supply were manufacturers $(53.8 \%$ of all shortages) and wholesalers ( $45.3 \%$ ) (Table 3). In $73.9 \%$ of cases, the cause of the shortage was unknown. For the remaining shortages, the causes were an increase in demand (19.8\% of all shortages), a manufacturing problem $(1.9 \%)$, lack of raw material $(1.6 \%)$, discontinuation of a product (i.e., product had been taken off the market; $1.6 \%$ ), a quality defect $(0.6 \%)$, or a natural disaster or other incident $(0.3 \%)$. For $95.9 \%$ of the shortages, national guidelines for managing drug shortages were not available, and each hospital managed their shortages through additional stocking. The personnel who managed shortages varied across the institutions: pharmacists (50.0\% of shortages), administrative staff (30.5\%), or pharmacy technicians (18.9\%).

Depending on the drug concerned, management of a shortage could be more or less complicated, in terms of both seeking alternatives and communicating the shortage to other health professionals. For more than half of the shortages (57.9\%), respondents estimated that they spent no more than $30 \mathrm{~min}$ managing the shortage. Only $6.3 \%$ of shortages required more than $120 \mathrm{~min}$. The main actions taken to manage drug shortages within the study hospitals were using another product ( $44.0 \%$ of shortages), obtaining the drug from another supplier (8.5\%), importing the product from abroad (5.7\%), and changing the institution's practices (5.3\%).

Participating pharmacists were asked to identify additional management strategies and tools in place within their respective institutions. Paradoxically, only pharmacists in the Spanish, Swiss, and Canadian hospitals used the national website for reporting drug shortages in their practices. Furthermore, only the hospitals in these 3 countries had a policy for increasing critical drug inventory levels, and only the hospitals in Switzerland and Canada had strengthened pertinent clauses in their calls for tender requiring pharmaceutical companies to develop plans to prevent breaks in the drug supply (i.e., a risk management program).

\section{DISCUSSION}

This descriptive study characterized drug shortages in a single hospital centre in each of 5 countries over a 4-week period in early 2018. According to calculated drug shortage ratios, the shortages seemed to be most important in the Swiss and Canadian hospitals, affecting just over $4 \%$ of the drugs normally in stock. Shortages affected between 3\% and $4 \%$ of drugs normally in stock in the Belgian and French hospitals (in descending order) and only about $1 \%$ of drugs normally in stock in the Spanish hospital. 
This single copy is for your personal, non-commercial use only.

For permission to reprint multiple copies or to order presentation-ready copies for distribution, contact CJHP at publications@cshp.ca

Table 1. Quantitative and Therapeutic Profile of Drug Shortages in a Representative Hospital in Each of 5 Countries

\begin{tabular}{|c|c|c|c|c|c|c|}
\hline \multirow[b]{2}{*}{ Variable } & \multicolumn{6}{|c|}{ Country; No. (\%) of Shortages* } \\
\hline & $\begin{array}{l}\text { Canada } \\
(n=84)\end{array}$ & $\begin{array}{l}\text { France } \\
(n=62)\end{array}$ & $\begin{array}{l}\text { Belgium } \\
(n=46)\end{array}$ & $\begin{array}{l}\text { Spain } \\
(n=28)\end{array}$ & $\begin{array}{l}\text { Switzerland } \\
(n=98)\end{array}$ & $\begin{array}{c}\text { Total } \\
(n=318)\end{array}$ \\
\hline \multicolumn{7}{|l|}{ Quantitative profile } \\
\hline $\begin{array}{l}\text { No. of drug manufacturers } \\
\text { with } \geq 1 \text { shortage }\end{array}$ & 28 & 30 & 19 & 16 & 42 & 135 \\
\hline \multicolumn{7}{|l|}{ Duration of drug shortage, days } \\
\hline Mean \pm SD & \multirow{2}{*}{$\begin{array}{c}55 \pm 61 \\
32(0-402)\end{array}$} & \multirow{2}{*}{$\begin{array}{l}35 \pm 83 \\
9(2-437)\end{array}$} & \multirow{2}{*}{$\begin{array}{c}51 \pm 47 \\
37(1-263)\end{array}$} & \multirow{2}{*}{$\begin{array}{l}51 \pm 63 \\
25(0-240)\end{array}$} & \multirow{2}{*}{$\begin{array}{c}186 \pm 301 \\
68(0-1771)\end{array}$} & $91 \pm 186$ \\
\hline Median (range) & & & & & & $31(0-1771)$ \\
\hline $\begin{array}{l}\text { No. of drug shortages from generic } \\
\text { manufacturers }\end{array}$ & $48 \quad(57)$ & $28(45)$ & $4 \quad(9)$ & $12(43)$ & $33(34)$ & $125(39.3)$ \\
\hline $\begin{array}{l}\text { No. of shortages involving } \\
\text { parenteral drugs }\end{array}$ & 41 (49) & $29(47)$ & 31 (67) & $17(61)$ & $73(74)$ & $191(60.1)$ \\
\hline Therapeutic class $¥$ & & & & & & \\
\hline Anti-infective agents & $15 \quad(18)$ & $18(29)$ & 7 (15) & $8(29)$ & $19(19)$ & $67(21.1)$ \\
\hline Central nervous system agents & $13(15)$ & $11(18)$ & $1 \quad(2)$ & $5(18)$ & $6 \quad(6)$ & $36(11.3)$ \\
\hline Cardiovascular drugs & $7 \quad(8)$ & $7(11)$ & $3 \quad(7)$ & $1 \quad(4)$ & $8 \quad(8)$ & $26 \quad(8.2)$ \\
\hline Antineoplastic agents & $1 \quad(1)$ & $6(10)$ & $1 \quad(2)$ & $5(18)$ & $11(11)$ & $24(7.5)$ \\
\hline Gastrointestinal drugs & (4) & $0 \quad(0)$ & (9) & $0 \quad(0)$ & $3(3)$ & $10(3.1)$ \\
\hline $\begin{array}{l}\text { Skin and mucous membrane } \\
\text { preparations }\end{array}$ & $9(11)$ & $0 \quad(0)$ & $4 \quad(9)$ & $4(14)$ & (7) & $24 \quad(7.5)$ \\
\hline Hormones & (6) & $0 \quad(0)$ & $6(13)$ & (7) & (1) & 14 (4.4) \\
\hline Anesthetics, local & (6) & 2 (3) & $5(11)$ & (0) & (2) & $14 \quad(4.4)$ \\
\hline Antihistamines & (4) & 1 (2) & $0 \quad(0)$ & (0) & (0) & $4(1.3)$ \\
\hline Autonomic drugs & (7) & $1(2)$ & $(2)$ & (4) & (3) & $12(3.8)$ \\
\hline Diagnostic agents & (4) & $0 \quad(0)$ & (7) & (0) & (3) & $9 \quad(2.8)$ \\
\hline $\begin{array}{l}\text { Electrolytic, caloric, and water } \\
\text { balance agents }\end{array}$ & $(2)$ & $4 \quad(6)$ & (7) & (0) & (5) & $14 \quad(4.4)$ \\
\hline Ointments, ophthalmic agents & (4) & $1 \quad(2)$ & (4) & (0) & (3) & $9 \quad(2.8)$ \\
\hline Serums, toxoids, vaccines & (2) & 3 (5) & (0) & (0) & (9) & $14 \quad(4.4)$ \\
\hline Smooth muscle relaxants & (1) & $0 \quad(0)$ & (0) & (0) & (0) & $1 \quad(0.3)$ \\
\hline Vitamins & (1) & $0 \quad(0)$ & (0) & (4) & (1) & $3(0.9)$ \\
\hline Radioisotopes & (0) & $0 \quad(0)$ & (0) & (4) & (0) & $1 \quad(0.3)$ \\
\hline Enzymes & (0) & $1(2)$ & (0) & (0) & (1) & $2(0.6)$ \\
\hline Blood formation and coagulation agents & $(0)$ & $1 \quad(2)$ & (7) & (0) & (4) & $8 \quad(2.5)$ \\
\hline Blood derivatives & (0) & $0 \quad(0)$ & (0) & (0) & (1) & $1 \quad(0.3)$ \\
\hline Expectorants and cough preparations & (0) & $0 \quad(0)$ & (0) & (0) & $1 \quad(1)$ & $1 \quad(0.3)$ \\
\hline Other & $(6)$ & $6(10)$ & $(7)$ & $(0)$ & $10(10)$ & $24 \quad(7.5)$ \\
\hline
\end{tabular}

SD = standard deviation.

*Except where indicated otherwise.

tFor drugs with an estimated date of return to the market later than February 2, 2018, the end date was arbitrarily defined as February 2, 2018, for purposes of calculating the duration of shortage.

$\ddagger$ According to the classification of the American Hospital Formulary Service.

These data seem to confirm the existence of a drug shortage problem in hospitals in many countries. However, the number of drug shortages varied by a factor of 3 across the study hospitals, which may suggest important variability among countries. In other words, although drug shortages are a global problem, their importance in particular countries seems disparate. Bochenek and others ${ }^{4}$ reported similar data from a survey conducted in 2017 in 28 countries in Europe and West Asia. Indeed, over the 3 years preceding their study, those authors observed a trend toward increasing drug shortages in France and Switzerland, and decreasing shortages in Belgium and Spain.

In the study reported here, the numbers of shortages were higher in the Canadian and Swiss hospitals than in the hospitals in the other 3 countries. No specific cause could be identified to explain these differences. At the international level, parallel drug export within the European Union might explain some of the drug shortages. Some countries, including France, have introduced legal requirements for wholesalers and pharmaceutical companies to address drug shortages; in France, these requirements include the obligation to implement a management plan for drug shortages of major interest (e.g., drugs for which treatment interruption is likely to be life-threatening) and a prohibition on export of any of these drugs. ${ }^{21}$ Similar measures are in place in other European countries, such as Spain, where the Spanish Agency for Medicines and Health Products may adopt measures to limit excessive export of medicinal products when 
This single copy is for your personal, non-commercial use only.

For permission to reprint multiple copies or to order presentation-ready copies for distribution, contact CJHP at publications@cshp.ca

Table 2. Drug Shortages by Manufacturer

Country; No. (\%) of Shortages*

\begin{tabular}{|c|c|c|c|c|c|c|c|c|c|c|c|c|}
\hline \multirow{2}{*}{$\begin{array}{l}\text { Manufacturer } \\
\text { Accord Healthcare }\end{array}$} & \multicolumn{2}{|c|}{$\begin{array}{l}\text { Canada } \\
(n=84)\end{array}$} & \multicolumn{2}{|c|}{$\begin{array}{l}\text { France } \\
(n=62)\end{array}$} & \multicolumn{2}{|c|}{$\begin{array}{c}\text { Belgium } \\
(n=46)\end{array}$} & \multicolumn{2}{|c|}{$\begin{array}{c}\text { Spain } \\
(n=28)\end{array}$} & \multicolumn{2}{|c|}{$\begin{array}{c}\text { Switzerland } \\
(n=98)\end{array}$} & \multicolumn{2}{|c|}{$\begin{array}{c}\text { Total } \\
(n=318)\end{array}$} \\
\hline & 0 & $(0)$ & 2 & (3) & 0 & (0) & 2 & (7) & 0 & (0) & 4 & $(1.3)$ \\
\hline Apotex & 8 & (10) & 0 & (0) & 0 & (0) & 0 & (0) & 0 & (0) & 8 & $(2.5)$ \\
\hline Arrow Pharmaceuticals & 0 & $(0)$ & 5 & (8) & 0 & (0) & 0 & (0) & 0 & (0) & 5 & $(1.6)$ \\
\hline Aspen Pharmacare & 4 & (5) & 2 & (3) & 0 & (0) & 0 & (0) & 4 & (4) & 10 & (3.1) \\
\hline B. Braun & 0 & (0) & 1 & (2) & 4 & (9) & 0 & (0) & 3 & (3) & 8 & $(2.5)$ \\
\hline Baxter & 1 & (1) & 0 & (0) & 0 & (0) & 0 & (0) & 1 & (1) & 2 & $(0.6)$ \\
\hline Bayer & 0 & (0) & 1 & (2) & 0 & (0) & 1 & (4) & 4 & (4) & 6 & (1.9) \\
\hline Bristol-Myers Squibb & 0 & (0) & 1 & (2) & 0 & (0) & 0 & (0) & 2 & (2) & 3 & $(0.9)$ \\
\hline Fresenius Medical Care & 1 & (1) & 0 & (0) & 0 & (0) & 0 & (0) & 5 & (5) & 6 & $(1.9)$ \\
\hline GSK & 3 & (4) & 2 & (3) & 1 & (2) & 2 & (7) & 8 & (8) & 16 & $(5.0)$ \\
\hline Hospira & 0 & (0) & 1 & (2) & 0 & (0) & 1 & (4) & 0 & (0) & 2 & $(0.6)$ \\
\hline Janssen Pharmaceutical & 0 & (0) & 1 & (2) & 1 & (2) & 0 & (0) & 0 & (0) & 2 & $(0.6)$ \\
\hline Kern Pharma & 0 & (0) & 0 & (0) & 0 & (0) & 2 & (7) & 0 & (0) & 2 & $(0.6)$ \\
\hline Meda Pharmaceuticals & 0 & (0) & 0 & (0) & 3 & (7) & 0 & (0) & 0 & (0) & 3 & $(0.9)$ \\
\hline Merck \& Co & 0 & (0) & 0 & (0) & 0 & (0) & 1 & (4) & 1 & (1) & 2 & (0.6) \\
\hline MSD & 0 & (0) & 4 & (6) & 8 & (17) & 0 & (0) & 8 & (8) & 20 & (6.3) \\
\hline Mylan & 1 & (1) & 11 & (18) & 5 & (11) & 2 & (7) & 0 & (0) & 19 & (6.0) \\
\hline NextPharma & 0 & (0) & 0 & $(0)$ & 0 & (0) & 0 & (0) & 5 & (5) & 5 & (1.6) \\
\hline Novartis & 1 & (1) & 1 & (2) & 1 & (2) & 0 & (0) & 2 & (2) & 5 & (1.6) \\
\hline O\&M Movianto & 0 & $(0)$ & 0 & (0) & 6 & (13) & 0 & (0) & 2 & (2) & 8 & (2.5) \\
\hline Pfizer & 15 & (18) & 2 & (3) & 3 & (7) & 6 & (21) & 5 & (5) & 31 & $(9.7)$ \\
\hline Pharmascience & 10 & (12) & 0 & (0) & 0 & (0) & 0 & (0) & 0 & (0) & 10 & (3.1) \\
\hline Sandoz & 6 & (7) & 3 & (5) & 2 & (4) & 0 & (0) & 1 & (1) & 12 & (3.8) \\
\hline Sanofi & 1 & (1) & 5 & (8) & 2 & (4) & 3 & (11) & 8 & (8) & 19 & $(6.0)$ \\
\hline Stiefel Laboratories & 0 & $(0)$ & 0 & (0) & 0 & (0) & 2 & (7) & 0 & (0) & 2 & $(0.6)$ \\
\hline Teva Pharmaceutical Industries & 9 & (11) & 3 & (5) & 0 & (0) & 2 & (7) & 0 & (0) & 14 & $(4.4)$ \\
\hline Other & 24 & (29) & 17 & (27) & 10 & (22) & 4 & (14) & 39 & (40) & 94 & (29.6) \\
\hline
\end{tabular}

${ }^{*}$ A value of zero indicates that either the company did not hold a contract with the particular study hospital or the company had no shortages with the hospital during the study period.

a drug is the sole product of its kind available on the Spanish market. ${ }^{22}$ Paradoxically, although parallel export restrictions are enforceable in other countries, they are not applied in Belgium. ${ }^{4}$

The median duration of drug shortages varied widely in this study, from 9 days in the French hospital to 68 days in the Swiss hospital. Given such long-term unavailability, it seems unlikely that drug shortages could be prevented simply by increasing stocks. Drug shortages have forced hospitals to develop new management strategies (e.g., identification of more than 1 provider for each drug, delay or deferral of care or procedures, prioritization of indications for medication therapy). Drug shortages thus raise concerns about continuity of care, as well as financial and ethical issues. Overall, maintenance of sufficient inventory, development of decision support tools, and optimization of inventory management are therefore essential. Indeed, Russell and others ${ }^{23}$ showed, through an analytical decision model, that in times of scarcity, efficiency-based allocation can lead to treatment for more patients than a "first come, first served" policy.

In the current study, the number of manufacturers implicated in the occurrence of at least 1 drug shortage ranged from a low of 16 (for the Spanish hospital) to a high of 42 (for the Swiss hospital). In all but the Belgian hospital, a high proportion of generic companies were involved in drug shortages; however, shortages were not limited to generic companies. The low profitability of the generics market, particularly in relation to price reduction and payment caps determined by governments, can contribute to drug shortages and to reductions in the number of manufacturers for a given market. ${ }^{24-26}$ Thus, although a singlesourcing procurement strategy can save money in the short term, it may contribute to drug shortages in the long term, by causing many potential suppliers to exit the market. In Belgium, the low profitability of generic drugs has led many generic drug companies to decline participation in tenders, and this trend can be expected to extend to biosimilars. ${ }^{27,28}$

More than half of the drug shortages in this study involved parenteral drugs, similar to data reported from the United States and several European countries. ${ }^{29,30}$ Increased regulatory requirements (e.g., good manufacturing practices) and controls at production sites have probably weakened the current market. Indeed, among the known causes of shortage, quality defects and manufacturing problems represented a total of $2.5 \%(8 / 318)$ of the shortages identified in this study. However, this is not a coincidence if shortages are affecting mainly drugs with more 
This single copy is for your personal, non-commercial use only.

For permission to reprint multiple copies or to order presentation-ready copies for distribution, contact CJHP at publications@cshp.ca

Table 3. Qualitative Profile of Drug Shortages in Each Hospital

\begin{tabular}{|c|c|c|c|c|c|c|c|}
\hline \multirow[b]{2}{*}{ Variable } & \multicolumn{7}{|c|}{ Country; No. (\%) of Shortages } \\
\hline & \multicolumn{2}{|c|}{$\begin{array}{l}\text { Canada } \\
(n=84)\end{array}$} & $\begin{array}{c}\text { France } \\
(n=62)\end{array}$ & $\begin{array}{l}\text { Belgium } \\
(n=46)\end{array}$ & $\begin{array}{c}\text { Spain } \\
(n=28)\end{array}$ & \multirow[t]{2}{*}{$\begin{array}{c}\text { Switzerland } \\
(n=98)\end{array}$} & \multirow[t]{2}{*}{$\begin{array}{c}\text { Total } \\
(n=318)\end{array}$} \\
\hline \multicolumn{6}{|c|}{ Data source used to identify drug shortages } & & \\
\hline Wholesaler & 82 & $(98)$ & $60(97)$ & $0 \quad(0)$ & $2(7)$ & $0 \quad(0)$ & $144(45.3)$ \\
\hline Manufacturer & 2 & $(2)$ & $0 \quad(0)$ & $46(100)$ & $25(89)$ & $98(100)$ & $171(53.8)$ \\
\hline Website & 0 & (0) & $0 \quad(0)$ & $0 \quad(0)$ & $0 \quad(0)$ & $0 \quad(0)$ & $0 \quad(0.0)$ \\
\hline Drug regulatory authorities & 0 & (0) & $2(3)$ & $(0)$ & (4) & $(0)$ & $3(0.9)$ \\
\hline Other institutions & 0 & (0) & $0 \quad(0)$ & $(0)$ & $(0)$ & (0) & $0 \quad(0.0)$ \\
\hline Other & 0 & (0) & $0 \quad(0)$ & (0) & (0) & (0) & $0 \quad(0.0)$ \\
\hline \multicolumn{8}{|l|}{ Cause of shortage } \\
\hline Shortage of raw material & 0 & $(0)$ & $1 \quad(2)$ & $(0)$ & $2 \quad(7)$ & $2 \quad(2)$ & $5 \quad(1.6)$ \\
\hline Manufacturing problem & 0 & (0) & $2(3)$ & (9) & (0) & (0) & $6 \quad(1.9)$ \\
\hline Quality defect & 0 & (0) & $0 \quad(0)$ & $(2)$ & (0) & (1) & $2(0.6)$ \\
\hline Increasing demand & 54 & (64) & $0 \quad(0)$ & (0) & (0) & (9) & $63(19.8)$ \\
\hline Product discontinued & 4 & (5) & $0 \quad(0)$ & (0) & (4) & (0) & $5(1.6)$ \\
\hline Natural disaster or other incident & 0 & (0) & $0 \quad(0)$ & $0 \quad(0)$ & $0 \quad(0)$ & $1 \quad(1)$ & $1(0.3)$ \\
\hline Unknown & 26 & (31) & $59(95)$ & 40 (87) & $25(89)$ & 85 (87) & $235(73.9)$ \\
\hline Other & 0 & $(0)$ & $0 \quad(0)$ & $1 \quad(2)$ & $0 \quad(0)$ & $0 \quad(0)$ & $1(0.3)$ \\
\hline \multicolumn{8}{|c|}{ Presence of national directive or regulation for managing shortage* } \\
\hline Yes & 0 & $(0)$ & $2(3)$ & $0 \quad(0)$ & $10(36)$ & $1 \quad(1)$ & $13(4.1)$ \\
\hline No & 84 & (100) & $60(97)$ & $46(100)$ & $18(64)$ & $97(99)$ & $305(95.9)$ \\
\hline \multicolumn{8}{|c|}{ Personnel in charge of managing shortaget } \\
\hline Pharmacist & 2 & $(2)$ & $7(11)$ & $46(100)$ & $6(21)$ & $98(100)$ & $159(50.0)$ \\
\hline Pharmacy technicians & 5 & (6) & $55(89)$ & $0 \quad(0)$ & $0 \quad(0)$ & $0 \quad(0)$ & $60(18.9)$ \\
\hline Administrative personnel or management & 77 & (92) & $0 \quad(0)$ & $(0)$ & $20(71)$ & $(0)$ & $97(30.5)$ \\
\hline Other & 0 & 0) & $0 \quad(0)$ & $(0)$ & $0 \quad(0)$ & $(0)$ & $0 \quad(0.0)$ \\
\hline Unknown & 0 & $(0)$ & $0 \quad(0)$ & $(0)$ & (7) & $(0)$ & $2(0.6)$ \\
\hline \multicolumn{8}{|c|}{ Estimated time spent on managing shortage } \\
\hline$<15 \mathrm{~min}$ & 57 & (68) & $55(89)$ & $0 \quad(0)$ & $5(18)$ & $(0)$ & $117(36.8)$ \\
\hline $15-30 \mathrm{~min}$ & 16 & (19) & $0 \quad(0)$ & $46(100)$ & $5(18)$ & $(0)$ & $67(21.1)$ \\
\hline $31-60 \mathrm{~min}$ & 0 & $(0)$ & $2(3)$ & $0 \quad(0)$ & $6(21)$ & $85(87)$ & $93(29.2)$ \\
\hline $61-120 \mathrm{~min}$ & 0 & (0) & $0 \quad(0)$ & (0) & $1 \quad(4)$ & $7 \quad(7)$ & $8(2.5)$ \\
\hline$>120 \min$ & 3 & (4) & $5 \quad(8)$ & (0) & $6(21)$ & (6) & $20(6.3)$ \\
\hline Unknown & 8 & (10) & $0 \quad(0)$ & $(0)$ & $5(18)$ & $(0)$ & $13(4.1)$ \\
\hline \multicolumn{8}{|l|}{ Actions implemented during shortage } \\
\hline Used product still in stock $\neq$ & 30 & (36) & $53(85)$ & $5(11)$ & $(4)$ & $4 \quad(4)$ & $93(29.2)$ \\
\hline $\begin{array}{l}\text { Obtained drug from another } \\
\text { health facility }\end{array}$ & 0 & $(0)$ & $0 \quad(0)$ & $0 \quad(0)$ & $(0)$ & $0 \quad(0)$ & $0 \quad(0.0)$ \\
\hline Obtained drug from another supplier & 21 & $(25)$ & $0 \quad(0)$ & $4 \quad(9)$ & $2(7)$ & $0(00)$ & $27 \quad(8.5)$ \\
\hline Used another product & 11 & (13) & $0 \quad(0)$ & $37(80)$ & $17(61)$ & $75(77)$ & $140(44.0)$ \\
\hline Imported drug from another country & 0 & $(0)$ & $2(3)$ & $0 \quad(0)$ & $3(11)$ & $13(13)$ & $18 \quad(5.7)$ \\
\hline Modified practices of the health facility & 10 & $(12)$ & $5 \quad(8)$ & (0) & $1 \quad(4)$ & $1 \quad(1)$ & $17 \quad(5.3)$ \\
\hline Other & 2 & $(2)$ & $0 \quad(0)$ & $0 \quad(0)$ & $3(11)$ & $5 \quad(5)$ & $10(3.1)$ \\
\hline Unknown & 10 & (12) & 2 (3) & NA & 1 (4) & NA & $13(4.1)$ \\
\hline \multicolumn{8}{|c|}{$\begin{array}{l}\text { NA = not applicable. } \\
\text { *Depending on the type of drug in short supply, the drug regulatory authorities may or may not issue recommendations to ensure patient safety } \\
\text { during the shortage. } \\
\text { tThe person managing a shortage may differ according to the type of drug in shortage or the reason for the shortage; for example, some actions } \\
\text { implemented during a shortage may require the skills of a pharmacist. } \\
\text { fHealth facilities usually have a stock of about } 2 \text { weeks for the main drugs used. Therefore, when a drug is in short supply at the manufacturer, } \\
\text { it may take a few days or a week before the hospital's stock declines to zero. Sometimes, however, the stock is insufficient to meet needs during } \\
\text { a manufacturer's shortage, and other actions must be implemented. }\end{array}$} \\
\hline
\end{tabular}

complex and costly manufacturing processes and low profit margins. Shortages of different drugs do not carry the same risk of medication incidents, and we believe that shortages of parenteral drugs are generally more critical. Indeed, the size of the market and the limited number of competitors often result in single-source drug production for an entire country. In contrast to the situation in Canada, membership in the European Union and the greater population density of European countries may 
promote competition and increase the number of alternatives available in national markets in Europe. We might therefore question the role of the European Union in the occurrence and prevention of drug shortages. Fostering trade between countries and importing products from abroad would probably mitigate the impact and consequences of drug shortages. Paradoxically, current measures, especially those in European countries, tend to limit exchanges of products to protect each country's population from the health risks associated with drug shortages. In addition, Health Canada allows, by exception, the importation of drugs without market authorization when required on an urgent basis. ${ }^{31}$ The same is true in Switzerland and Belgium, where, in the event of a stock-out situation, the holder of market authorization must apply to market a foreign drug for a limited period..$^{32-34}$

Many causes of shortages have been identified in the literature. ${ }^{35-37}$ However, the causes are usually unknown, as was the case for $73.9 \%$ of the shortages in our study. This result points to a substantial lack of transparency in the pharmaceutical industry. For instance, pharmaceutical companies are not required to disclose the production sites of drugs. As a result, it can be difficult to anticipate shortages of specific drugs when a single plant is facing manufacturing issues, and it is correspondingly difficult for pharmacists to guard against drug shortages in their daily practice. Although shortages differ in terms of their importance and the associated risks for patients, each shortage represents administrative and pharmaceutical concerns that will increase workload for the entire staff of an institution and will similarly increase the risk of errors.

Participants in this study generally spent no more than 30 min managing each shortage (57.9\% of cases) because they had another locally available solution (e.g., some product still in stock, an alternative option readily available). Thus, management of only $6.3 \%$ of the drug shortages identified required more than $120 \mathrm{~min}$; in these cases, more complex actions were needed, such as modification of the hospital's practices or importation of products from abroad. De Weerdt and other ${ }^{38}$ investigated the time spent by Belgian hospital pharmacists on supply problems and drug shortages. They found that the median time spent on drug supply problems was $109 \mathrm{~min} /$ week (minimum $40 \mathrm{~min} /$ week, maximum $216 \mathrm{~min} /$ week). With an average of 7 new drug shortages per week in the facilities in our study, each requiring 15 to $30 \mathrm{~min}$ of time, our results are therefore of the same order of magnitude (total weekly time 105 to $210 \mathrm{~min}$ ).

This study has highlighted a substantial disparity in drug shortages among hospitals in different countries. In the face of this problematic situation, the government, regulatory authorities, and health care professionals in each country have set up their own tools to prevent and manage drug shortages.

Comparisons across different countries should allow hospitals and pharmacists to learn from experiences elsewhere, and the value of such comparisons should not be underestimated. In addition, establishing effective communication networks and creating ongoing collaborative relationships among all stakeholders, including the pharmaceutical industry, would enable proactive action.

This study had some limitations. It was a descriptive study based on data from a single hospital in each country. As such, it described shortages at the facility level, and the data may not be representative of shortages at the national level. In fact, a previous comparison of drug shortages in Canada and France showed that a greater number of shortages were officially reported in Canada than in France at the national level, but the numbers of shortages were similar at the level of individual institutions. ${ }^{20}$ During the period of the current study (early 2018), the numbers of drug shortages reported on national drug shortage reporting sites were 2165 in Canada, ${ }^{39} 827$ in Belgium, ${ }^{40} 261$ in Spain, ${ }^{41} 126$ in France, ${ }^{42}$ and only 28 in Switzerland. ${ }^{43}$ However, these official data should be interpreted with caution because reporting methods vary among these countries. For example, in Belgium, only temporary nonavailability of drugs over 14 days must be declared. In France, the website of the Agence nationale de sécurité des médicaments et des produits de santé reports only shortages of drugs of major therapeutic interest. In Switzerland, reporting of drug shortages is mandatory only for a limited number of critical drugs. In Canada, shortages reported at the drug shortage website theoretically include all known drug shortages; however, declarations are made by the manufacturers themselves, who are free to update the data at any time. In Spain, shortages are declared by health authorities of the autonomous communities (first-level political/administrative divisions within the country's constitutional structure), when detected by these bodies, or by the holders of drug marketing authorizations. However, it is likely that the true number of drug shortages differs among the countries included in this study, regardless of the specified declaration requirements.

Data were collected over a short period (about 1 month). A longitudinal study, extending over a period of at least 1 year, could increase the robustness of the results but would be time-consuming. Nonetheless, participants in the current study considered the reported data as being representative of current practice in their respective institutions. The study did not assess the criticality of identified drug shortages. Not all shortages have the same importance, nor do they carry the same risks for patients; however, each shortage does affect the quality of care, the workload of health care professionals, and the financial burden on the institution. Some previous studies have looked at the clinical consequences of shortages. For example, Stockwell ${ }^{35}$ established a link between a shortage of norepinephrine in the United States in 2011 and rates of death from septic shock in relation to the therapeutic alternatives used: across the 27835 patients in 26 hospitals with a norepinephrine shortage lasting at least 3 months, there was a significant $4 \%$ increase in deaths from 
This single copy is for your personal, non-commercial use only.

For permission to reprint multiple copies or to order presentation-ready copies for distribution, contact CJHP at publications@cshp.ca

septic shock related to shortage of this drug. Drug shortages also have a notable financial impact on health care systems. Alevizakos and others ${ }^{44}$ investigated price changes for drugs affected by shortages in the United States between 2005 and 2016 and found a significant increase in prices after a period of shortage. Therefore, drug shortages might have a cascading effect, including price increases and shortages of alternative drugs. The daily management of drug shortages thus requires mobilization of substantial human and financial resources to minimize the impact of shortages on the quality and safety of care.

\section{CONCLUSION}

This descriptive study identified a large number of shortages in 1 representative hospital in each of 5 different countries in early 2018. Further studies are required to better describe the current status of drug shortages in these countries. This study highlights the need to focus on this situation, to involve all stakeholders in efforts to prevent and address drug shortages, and to foster international collaboration on this problem.

\section{References}

1. Gray A, Manasse HR. Shortages of medicines: a complex global challenge [editorial]. Bull World Health Organ. 2012 [cited 2018 Feb 2];90(3): 158-158A. English, French. Available from: https:/www.who.int/bulletin/ volumes/90/3/11-101303.pdf

2. Evaluation of medicines shortages in Europe: an EAEPC contribution to the birgli report. Brussels (Belgium): European Association of Euro-Pharmaceutical Companies; 2014 [cited 2018 Feb 9]. Available from: https:/www.eaepc.org/ images/News/EAEPC_Contribution_to_the_birgli_report.pdf

3. Report on drug shortages for calendar year 2016. Silver Spring (MD): US Department of Health and Human Services, Food and Drug Administration; 2017 [cited 2018 Feb 9]. Available from: https://www.fda.gov/downloads/ Drugs/DrugSafety/DrugShortages/UCM561290.pdf

4. Bochenek T, Abilova V, Alkan A, Asanin B, de Miguel Beriain I, Besovic Z, et al. Systemic measures and legislative and organizational frameworks aimed at preventing or mitigating drug shortages in 28 European and Western Asian countries. Front Pharmacol. 2018;8:942.

5. De Weerdt E, Simoens S, Casteels M, Huys I. Toward a European definition for a drug shortage: a qualitative study. Front Pharmacol. 2015;6:253.

6. Meeting report: technical definitions of shortages and stockouts of medicines and vaccines. Geneva (Switzerland): World Health Organization; 2016 [cited 2018 Feb 9]. Available from: http://apps.who.int/medicinedocs/documents/ s23146en/s23146en.pdf

7. Drug shortages [webpage]. Silver Spring (MD): US Food and Drug Administration; [cited 2018 Feb 9]. Available from: https://www.fda.gov/ Drugs/DrugSafety/DrugShortages/default.htm

8. Medicine shortages [webpage]. London (UK): European Medicines Agency; [cited 2018 Feb 9]. Available from: www.ema.europa.eu/ema/index.jsp?curl= pages/regulation/general/general_content_000588.jsp\&mid=WC0b01ac $05807477 \mathrm{a} 5$

9. Medicines shortages [webpage]. Brussels (Belgium): European Association of Hospital Pharmacists; [cited 2018 Feb 9]. Available from: www.eahp.eu/ practice-and-policy/medicines-shortages

10. FIP addressing global medicines shortages. The Hague (Netherlands): International Pharmaceutical Federation; 2018 [cited 2018 Feb 9]. Available from: https://www.fip.org/Medicines-shortages

11. Article L5124-6. In: Code de la santé publique [France]. 2004 Aug 11 [updated 2016 Jan 28; cited 2018 Feb 9]. Available from: https:// www.legifrance.gouv.fr/affichCodeArticle.do;jsessionid=C0A94AD313C65E
1F29C7D8C140548E17.tplgfr30s_3?idArticle=LEGIARTI000006689983 \&cidTexte=LEGITEXT000006072665\&categorieLien=id\&dateTexte= 20040810

12. Circulaire $n^{\circ} 577$ aux titulaires d'autorisation de mise sur le marché ou d'enregistrement de médicament à usage humain ou de médicaments à usage vétérinaire. Brussels (Belgium): Agence fédérale des médicaments et des produits de santé; 2011 Feb 15 [cited 2018 Feb 9]. Available from: https://www.afmps.be/sites/default/files/downloads/circulaire-577-201102-15.pdf

13. Real Decreto 824/2010, de 25 de junio, por el que se regulan los laboratorios farmacéuticos, los fabricantes de principios activos de uso farmacéutico y el comercio exterior de medicamentos y medicamentos en investigación [Spain]. 2010 [revised 2013 Oct 19; cited 2018 Mar 9]. Available from: www.boe.es/ buscar/pdf/2010/BOE-A-2010-10827-consolidado.pdf

14. Ordonnance sur le bureau de notification pour les médicaments vitaux à usage humain. 531.215.32. Geneva (Switzerland): Conseil Fédéral suisse; 2015 Aug 12 [cited 2018 Feb 9]. Available from: https://www.admin.ch/ opc/fr/classified-compilation/20141823/201510010000/531.215.32.pdf

15. Article C.01.014.9. In: Food and Drug Regulations, C.R.C., c. 870. Available from: https://laws-lois.justice.gc.ca/eng/regulations/C.R.C.\%2C_c._870/ page-94.html\#docCont [cited 2018 Feb 9].

16. Article 23a. In: Directive 2001/83/EC of the European Parliament and of the Council of 6 November 2001 on the community code relating to medicinal products for human use. European Parliament and Council of the European Union; 2001 [cited 2018 Apr 30]. p. 39. Available from: https:// ec.europa.eu/health/sites/health/files/files/eudralex/vol-1/dir_2001_83_ consol_2012/dir_2001_83_cons_2012_en.pdf

17. David C, Mazaud P, Dambrine M, Delpech L, Bouchrim L, Granier E, et al. Gestion des ruptures d'approvisionnement de médicaments dans un établissement de santé. Pharm Hosp Clin. 2017;52(2):196-207.

18. Shortages catalogue [webpage]. London (UK): European Medicines Agency; [cited 2018 Apr 30]. Available from: www.ema.europa.eu/ema/ index.jsp?curl=pages/regulation/document_listing/document_listing_000376. jsp\&mid=WC0b01ac05807477a6

19. 2014 medicines shortage survey. EAHP's 2014 survey of the medicines shortage problem. Brussels (Belgium): European Association of Hospital Pharmacists; [cited 2018 Apr 30]. Available from: http://www.eahp.eu/practice-andpolicy/medicines-shortages/2014-medicines-shortage-survey

20. Rousseau A, Meunier A, Derain L, Locher F, Bussières JF. Comparaison transversale des ruptures de médicaments en France et au Canada. Pharm Hosp Clin. 2017;52(2):160-7.

21. Bocquet F, Degrassat-Théas A, Peigné J, Paubel P. The new regulatory tools of the 2016 Health Law to fight drug shortages in France. Health Policy. 2017;121(5):471-6.

22. Article 101,c,22 and Article 102,1. In: [Law 29/2006 of July 26, on guarantees and rational use of medicines and medical devices] [Spain].

23. Russell HV, Bernhardt MB, Berg S. Using decision modeling to guide drug allocation during a shortage [special report]. Pediatr Blood Cancer. 2017; 64(7):e26331.

24. Heiskanen K, Ahonen R, Kanerva R, Karttunen P, Timonen J. The reasons behind medicine shortages from the perspective of pharmaceutical companies and pharmaceutical wholesalers in Finland. PLoS One. 2017;12(6): e0179479.

25. Dranitsaris G, Jacobs I, Kirchhoff C, Popovian R, Shane LG. Drug tendering: drug supply and shortage implications for the uptake of biosimilars. Clinicoecon Outcomes Res. 2017;9:573-84.

26. Labrie Y. Les notes économiques: Comment éviter les pénuries de médicaments? Montréal (QC): Institut économique de Montréal; 2012 Jul [cited 2018 Feb 9]. Available from: www.iedm.org/files/note0912_fr.pdf

27. Dylst P, Vulto A, Simoens S. Overcoming challenges in market access of generic medicines in the European Union. J Generic Med. 2012;9(1):21-8.

28. Convention pour relancer les médicaments biosimilaires en Belgique [webpage]. Brussels (Belgium): Institut national d'assurance maladie-invalidité; [cited 2018 Mar 7]. Available from: www.riziv.fgov.be/fr/themes/cout-remboursement/ par-mutualite/medicament-produits-sante/prescrire-medicaments/Pages/ medicaments-biosimilaires.aspx\#.WqAGp2rOVph 
This single copy is for your personal, non-commercial use only.

For permission to reprint multiple copies or to order presentation-ready copies for distribution, contact CJHP at publications@cshp.ca

29. McLaughlin M, Kotis D, Thomson K, Harrison M, Fennessy G, Postelnick M, et al. Effects on patient care caused by drug shortages: a survey. J Manag Care Pharm. 2013;19(9):783-8.

30. Pauwels K, Huys I, Casteels M, Simoens S. Drug shortages in European countries: a trade-off between market attractiveness and cost containment? BMC Health Serv Res. 2014;14:438.

31. Drugs - special access to drugs and health products [webpage]. Ottawa (ON): Health Canada; [cited 2018 Feb 9]. Available from: https://www.canada.ca/en/health-canada/services/drugs-health-products/ special-access/drugs.html

32. Article 1, paragraph 2, section C, and Article 66. In: Federal Act on Medicinal Products and Medical Devices (Therapeutic Products Act) (TGTh, RS 812.21) [Switzerland].

33. Autorisation spéciale. Obtention de médicaments non autorisés ou non disponibles en Suisse. Swissmedic; [cited 2018 Feb 9]. Available from: https:// www.swissmedic.ch/swissmedic/fr/home/medicaments-a-usage-humain/ bewilligungen_zertifikate/autorisation-speciale.html

34. Commercialisation/ indisponibilité [webpage]. Brussels (Belgium): Agence fédérale des médicaments et des produits de santé; [cited 2018 Mar 7]. Available from: https://www.afmps.be/fr/humain/medicaments/medicaments/ distribution/indisponibilite

35. Stockwell S. Norepinephrine shortage led to increased deaths from septic shock. Am J Nurs. 2017;117(7):15.

36. Reed BN, Fox ER, Konig M, Jackevicius CA, Masoudi FA, Rabinstein AA, et al. The impact of drug shortages on patients with cardiovascular disease: causes, consequences, and a call to action. Am Heart J. 2016;175:130-41.

37. Ottino G, Lebel D, Bussières JF. Perspective face aux causes des ruptures d'approvisionnement de médicaments. Pharmactuel. 2012;45(3):207-12.

38. De Weerdt E, De Rijdt T, Simoens S, Casteels M, Huys I. Time spent by Belgian hospital pharmacists on supply disruptions and drug shortages: an exploratory study. PLoS One. 2017;12(3):e0174556.

39. Drug shortages homepage [website]. Drug Shortages Canada; [cited 2018 Mar 5]. Available from: https://www.drugshortagescanada.ca/

40. Médicaments indisponibles [webpage]. Brussels (Belgium): Agence fédérale des médicaments et des produits de santé; [cited 2018 Mar 5]. Available from: https://www.afmps.be/fr/items-HOME/indisponibilites_de_medicaments

41. Supply problems [website]. Agencia Español de Medicamentos y Productos Sanitarios, Medicine Online Information Center; [cited 2018 Mar 5]. Available from: https:/cima.aemps.es/cima/publico/listadesabastecimiento.html

42. Ruptures de stock des médicaments [website]. Paris (France): Agence nationale de sécurité du médicament et des produits de santé; [cited 2018 Mar 5]. Available from: http://ansm.sante.fr/S-informer/Informations-de-securiteRuptures-de-stock-des-medicaments

43. Bureau de notification [website]. Berne (Switzerland): Office fédéral pour l'approvisionnement économique du pays; [cited 2018 Mar 5]. Available from: https:/www.bwl.admin.ch/bwl/fr/home/themen/heilmittel/ meldestelle.html

44. Alevizakos M, Detsis M, Grigoras CA, Machan JT, Mylonakis E. The impact of shortages on medication prices: implications for shortage prevention. Drugs. 2016;76(16):1551-8.
Manon Videau is a PharmD candidate with the Faculty of Pharmacy (ISPB), Université Claude Bernard Lyon 1, Lyon, France, and a Research Assistant with the Pharmacy Practice Research Unit, Pharmacy Department, Centre hospitalier universitaire Sainte-Justine, Montréal, Quebec.

Lotfi Chemali is a PharmD candidate with the Faculty of Pharmacy, Université Paris Descartes, and is also a student intern with the Pharmacy Service, Hôpital Necker-Enfants malades, Paris, France.

Cyril Stucki, DPharm, is a Pharmacist with the Pharmacy Service, Hôpitaux universitaires de Genève, Geneva, Switzerland.

Mar Saavedra-Mitjans, DPharm, was, at the time of this study a Pharmacist with the Pharmacy Service, Hôpital de Santa Creu i Sant Pau, Barcelona, Spain

Samuel Largana, DPharm, is a Pharmacist and specialist candidate in hospital pharmacy with the Pharmacy Service, Centre hospitalier régiona de la Citadelle, Liège, Belgium.

Aurélie Guerin, DPharm, is a Pharmacist with the Pharmacy Service, Hôpital Necker-Enfants malades, Paris, France.

Pascal Bonnabry, DPharm, is Pharmacist and Head of the Pharmacy Service, Hôpitaux universitaires de Genève, Geneva, Switzerland.

Blaise Delhauteur, DPharm, is Pharmacist and Head of the Pharmacy Service, Centre hospitalier régional de la Citadelle, Liège, Belgium.

Thierry Van Hees, DPharm, is Pharmacist and Head of Clinical Pharmacy Services, Université de Liège, Liège, Belgium.

Denis Lebel, BPharm, MSc, FCSHP, is Assistant Director of Patient Care, Teaching and Research, Pharmacy Practice Research Unit, Pharmacy Department, Centre hospitalier universitaire Sainte-Justine, Montréal, Quebec.

Jean-François Bussières, BPharm, MSc, MBA, FCSHP, FOPQ, is Head, Pharmacy Practice Research Unit, Pharmacy Department, Centre hospitalier universitaire Sainte-Justine, and Clinical Professor, Faculty of Pharmacy, Université de Montréal, Montréal, Quebec.

Competing interests: None declared.

Address correspondence to:

Jean-François Bussières

Pharmacy Department

Centre hospitalier universitaire Sainte-Justine

3175, chemin de la Côte Sainte-Catherine

Montréal QC H3T 1C5

e-mail: jf.bussieres.hsj@ssss.gouv.qc.ca

Funding: None received.

Acknowledgement: The authors would like to thank Peggy Robinson for assistance, in advance of submission, with the English-language presentation 